\title{
Influence of Product Placements in Films and Television on Consumers Brand Awareness
}

\author{
Sunita Kumar \\ Assistant professor, School of Business Studies Social Sciences. \\ Christ University, Bangalore, Deeksha Kakkar
}

\begin{abstract}
Today marketers are hugely making use of product placements in films and television. Product placements are being thought to be more beneficial as they are incorporated in the storyline and therefore this is hard to be missed by the viewers. The objective of the research is to find the reason for people to connect to products, their attitude towards product placements and how this attitude influences their brand awareness and buying. There have been studies before showing why marketers and consumers are preferring product placements over commercial advertisements however this study focusses on the effect of product placements on consumer brand awareness. The data for this research has been collected by a questionnaire that includes questions on general opinion as well as the influence of product placements on Brand awareness. The data has been analyzed using Advance Analytics Methods (Random Forest and Association Analysis). The former method helped in identifying the important factors and later method helped to see the various combination of factors influencing product placements in films and television.
\end{abstract}

KeyWords: Product placements, Films, Television, Attitudes, Connect, Influence, Consumer buying behaviour, Consumption patterns, Brand awareness

\section{INTRODUCTION}

Product placement is an advertising method and tool that includes products in entertainment programs such as movies, TV programs and video games, with a specific objective. Product placements are popularly seen in the following formats:

- visual figures in which the product appears within the content

- actual product use by a celebrity in the film or TV show

- dialogues spoken by an actor that consist of the product /brand name

With every passing day, product placement is popularly growing among marketers for two main reasons. First, product placements that can be seen today are subtle in nature, therefore, they do not distract the viewers' substantial attention from the main content of the program or film. Eventually, the viewer may believe that this placement has been incorporated by the producers of the content themselves and not by the marketers, with the sole aim of promoting their products. This increases the credibility of the placement as well as of the product itself in the minds of the audience.

Secondly, entertainment programming, like television today, is combined with the internet which may facilitate a viewer to buy a product by simply pointing their remote to it, when they see it as a placement onscreen. This will increase the suitability of making purchases and will also increase the role of product placements leading to such purchases and brand awareness. 
With this development, product placement may become a dominant marketing strategy tomorrow.

Product placement is a marketing strategy that advanced a few decades ago. However, the advantages of product placements have lead professionals and various companies to involve themselves in product placement activities to obtain various levels of productivity. One of the major differences of product placement in television and films as compared to other advertising media is the significance of factors, such as setting and environment within which the product is displayed or demonstrated.

\section{REVIEW OF LITERATURE}

Product placement as an advertising tool has been extensively explored. Belch and Belch (2004) indicated in their study that product placement is most effective when it is used in a combination with marketing communication methods, for example integrating all the strategic approach and coordination of the different communication functions together. The main purpose of this integration is to avoid duplication. Gillespie, Joireman, and Muehling (2012) specified that the major portion of the previous study on product placement has tried to study the impact of product placement on consumer attitude and product (Balasubramanian, Karrh, and Patwardhan, 2006; Karrh, 1998). Past research studies discovered normative influence on product placement effects (Noguti and Russell 2014).

Product placement is also known as brand placement depending on the situation where the product or brand has been emphasised (Karrh, 1998). If we analyse more closely, now Product placement has moved very close to conventional marketing domain as customers are more marketing savvy and even the method has become very noticeable. Product placement is also used with alike objectives as advertising, such as greater than before awareness, interest, target to purchase, and altered behaviour, but with different viewpoints. Among the various uses of product placement in different kinds of media, several studies have talked about the impact of product and brand placement in movies. The effects of product placement have been observed by several studies in a traditional setting (Nelson and Deshpande, 2013), to discover the financial growth of product placement in movies (Karniouchina, Uslay, and Erenburg, 2011), and placement setting and obviousness (Wiles and Danielova, 2009). There have been many other types of research that have measured the effects of product placement in television shows (Gillespie, Joireman, and Muehling, 2012; Hackley and Tiwsakul, 2012) and video-game advertisements (Hang, 2014). Previously, studies have been undertaken to determine the effects on consumers of product placements (Auty and Lewis, 2004; Russell 2002, cited in Noguti and Russell, 2014) by highlighting the on-going decrease in television viewership with the increase in digital media. It is also debatable that these days the impact of traditional marketing efforts, like advertising - on TV, on radio, or on print media - is continuously decreasing due to social and technological changes, which includes the consumers' growing dislike of obvious advertising or increase in the use of DVDs and digital platforms, allowing the consumers to easily avoid the ads being aired on TV (Lawrence, 1989; Alwitt and Prabhaker, 1994; Zazza, 2002; Mack, 2004). Various studies have also recognised the usefulness of product placement with regard to recognition (Brennan and Babin, 2004), recollection and approach (Gupta and Gould, 1997).

The theory of reasoned action (TRA), says that a person's beliefs about the expected results will affect the setting up of attitudes that in turn will affect the behavioural intentions (Ajzen and Fishbein, 1980). Encoding variability theory; establishes that reciting a product placement with small changes can increase the viewer's memory of the product (Singh, Mishra, 
Bendapudi, and Linville, 1994) and provide learning through the recurrence of product placement. Increasing media exposure also influences consumers' attitudes and behaviours through product placement (Johnstone and Dodd, 2000).

Brand awareness includes two factors- brand recognition \& recall; and procurement and the utility of a product. Brand recognition and recall represent the depth while the buying and usage practices of a product represents the breath. Brand image impacts how customers relate themselves with a brand, which positively should be strong (relevance and consistency), favourable (desirability and deliverability), and unique (points-of-parity and points-ofdifference) (Keller, 2008). Brand attitudes eventually decide the consequences. For example, brand loyalty represents less exposure to catastrophes and rival engagements, larger margins, more elasticity to decrease in price (gaining more customers) and more inelasticity to increase in price (losing fewer customers), better opinions regarding the product, opportunities for outspreading the brand, greater trade cooperation (value chain), licensing opportunities, and increased marketing communication effectiveness and efficiency (Keller, 2008). The Associative Network Memory Model, is a model for understanding how product placement works (Anderson, 1983; Wyer and Srull, 1989). In the model, recall represents the process by which an individual identifies the product from memory, while recognition refers to being able to differentiate the product from another (Johnstone and Dodd, 2000). Here, memory can be seen as a grid of nodes and connecting links, in which the nodes representing blocks of data and links represent the connections between one piece of information and another. The information may be verbal, visual or contextual in nature (Keller, 2008). There is also a study by Janiszewski, Noel, and Sawyer (2003), which looked into the relationship between advertising repetition and consumer memory, signifying that "understanding how different types of repeated ads are received and remembered can provide insight into how to make advertising more real" (Janiszewski, Noel, and Sawyer, 2003). It was discovered that a repetition of advertisements, along with strategic product placement, will form a reminder in the mind of consumers, which will lead to brand awareness (Belch and Belch, 2004). Also, increasing media exposure increases the chances of subconscious influence from product placements. (Johnstone and Dodd, 2000). Therefore, consumers learn by seeing the protagonist's behaviours leading to the required results, thereby 'experiencing' the product or brand featured in a movie, TV program, or video game (Balasubramanian, 1994). A suitable example would be, Matthew McConaughey's portrayal of Brandon Lane in the movie, Two for the Money - getting a Mercedes SL600 to underline his new job position. Such instances could function as a stimulus, which, if complementary with the consumer's self-image, can inform and reinforce the social status of a consumer aspiring to emulate the character displayed. (Markin, 1979).

Product placements that are displayed in movies as well as on television shows grab the attention of the viewers and helps in creating an acceptance for the brand. It eventually leads to brand recall among the consumers while they are shopping and deciding what to purchase. Also, they find out about the other factors that are connected and contribute to product placement which includes celebrity endorsements, references, and emotions. The objective of this study is to identify if product placements affect consumers buying decisions, and how. The research methodology was completed by using 104 respondents who were targeted with a questionnaire with 39 questions about how product placements influenced brand recall. (Sharma \& Nayak, March 2015)

Today, all the big brands want to place their products and reach out to their potential customers with the help of mass media. This helps them not only to reach out to a large number of people but also to make a deep and long lasting impact. This article brings out the effectiveness and the impact of repetition of product placements in movies and television. It compares the repetition of the product 
placements that are bold in nature, with the ones that are subtle. The article brings out the kind of attitude that people have towards highly repetitive product placement ads and compares them to how people react to the less repetitive product placement ads. It has been found that repetition of strong/bold brand placement ads have a negative impact on the attitude that the consumers show towards the brand. On the other hand, subtle placement ads have a positive impact on the brand attitude of consumers. Also, the marketers should evaluate all the available options for placing their products as its repetition will have a huge influence of the brand on the attitudes of consumers. (Homer, 2009)

(Taejun, Yongjun, \& Federio, 2011) in their article investigates into the attitudes of the US and Korean students towards product placements via three media i.e. films, TV shows, and songs. They also look into the level of acceptability that the students were found to hold towards the product placement ads depending on the type of media and the nature of the placements. In order to retain the results, an online survey of 471 college students in Korea and US was taken. Korean students were found to more strongly support the government interferences than the American students. The cultural differences were also reflected in the acceptability of the students for the product placements. Here the weak point is that only two countries were taken to show the difference between the various kinds of product placements. The findings also showed that more caution is needed while putting forth a product placement in Korea than in the US.

(Habil, 2015) talks about the indicators and methodologies that are available to the researchers and marketers in order to evaluate product placement shown in a film or a TV show. The first methodology focuses on how a specific placement is perceived as a media appearance. Here, the following factors are considered: number of brand placements, duration of brand placements, full or partial placements, active or passive placements, measuring effectiveness at the consumer level, social media buzz, eye tracking tests, and costs incurred. The broader approach involves the marketing and communication impacts and effectiveness. This approach is measured with the following factors: raising awareness, brand recall, image development, expansion of target audience, development of positioning, internal marketing etc. These methods are not widely acceptable today because they are new, however, they cover all aspects that are useful in theory and in practice. To measure the effectiveness of product placement in Hindi movies as compared to Hindi TV shows. As advertisers are shifting these ads from commercial breaks to product placements in films, they showing that it is the right time to find out which medium and platform (films or tv shows) is more effective in promoting the brand. Data was collected with the help of a questionnaire. Responses were collected from 250 students pursuing their post-graduation who watched Hindi films and TV shows. The research article provides useful results for practitioners such as media planners, advertising agencies, brand managers, film script writers and producers for increasing the positive impacts of their product placements. (Patel \& Chauhan, April 2013)

Product Placements are seen to be strongly emerging as a method of marketing communication today. However, a lot of doubts can be raised about the advantages, disadvantages, effectiveness and impacts of product placements. This article explores the pros and cons of product placement as a marketing strategy. It highlights the ways in which product placement helps to create higher value and impact on the viewers as compared to other types of promotions. In researcher opinion, too product placements can be more effective as compared to other forms of promotions, as today there are new ways to capture audience attention with the advancement in technology people are being able to ignore or skip commercials/advertisements which are put forth by other media. The study to evaluate product placement as a marketing communication strategy was also undertaken in the US. (Soba \& Aydin, 2013) 
The article explores the impact on viewing advertisements and product placements on television and how they impact consumption behaviours and perceived body images. It shows that the effect is dissimilar for males and females. It does not influence the consumption behaviour of males. On the other hand, it increases self-disagreement, which eventually leads to an alteration in consumption behaviour. However, for both sides, it increases body dissatisfaction. To obtain the required results, a questionnaire was used for a sample of 241 students with 58.8\% females. (Eised \& Moller, 2006)

Product Placement as a marketing tool is majorly used to increase attention, interest and give rise to the purchase motive of the potential consumers. Taking various applications of product placements in automobile brands, the article examines product placements via various forms of media to create familiarity, awareness and to influence the purchase intentions of the consumer. It discovers how brand awareness and brand familiarity from such product placements affect brand image and how this brand image, in turn, affects the purchase intentions of consumers. For this study, the data was collected with the help of a survey and quantitative analyses were used to test the hypotheses. (Guennemann, 2014)

The article talks about how youngsters perceive the commercial breaks and the product placements shown during reality shows. The article takes three aspects into consideration which includes the extent to which youngsters watch reality shows and the extent to which they remember the products advertised during the commercial breaks and product placements during the show. While it is said that commercial breaks have a larger impact, the majority of people skip these breaks and are yet able to retain the product placements viewed during the show. (Mircea \& Elena, 2015)

The popularity of product placements, as a practical alternative to traditional commercials, has been increasing rapidly. The aim of this paper is to mainly focus and analyze product placements within movies, television programmes and video games. Researches were undertaken in the US investigating product placement showed that effectiveness through memory related measures and consumer attitudes control product placements. However, studies investigating effects of product placement on measures besides the ones that influence memory and attitudes are exceptionally rare. A total of 73 academic studies on product placement yielded invaluable results and implications of showcasing product placements on each medium. (Karışık, 20 Years of Research on Product Placement in Movie, Television and Video Game Media, 2014)

There have been a number of studies done before on the impact of product placements on the attitudes of the viewers. However, the Research Gap that can be seen here is how people relate to a product after being exposed to a product placement and how a product placement affects the consumer's brand awareness and buying. The research undertaken focusses on this aspect. It has been tried in finding out if consumers make purchase decisions on the basis of a product placement, if they are able to recall a product placement while making a purchase, if they find product placements disruptive as a consumer and if watching more reality shows (as they include more product placements) affects their buying behavior.

\section{Objectives of the study}

\section{RESEARCH METHODOLOGY}

- To explore the degree of brand awareness created by product placements in the minds of the viewers

- To determine the effect of product placements on the buying and consumption pattern of the viewers

H1: Product Placements endorsed by celebrities have a substantial impact on the brand awareness of the viewers. 
H2: Product Placements in electronic media influence consumer buying behaviour

\section{Sample Size}

A sample size of $\mathbf{1 7 0}$ participants have been undertaken for this research.

The target sample includes respondents from both genders ageing from 18-50 years as this age group is the most exposed to television and film viewing. This will also give us an idea how different age groups get affected by various product placements.

\section{DATA ANALYSIS}

This section details out the various steps taken for data analysis and their respective outcomes. The technology used are R (3.3.2) and RStudio (1.0.44). The Library used for analysis are "random Forest" and "arules".

\section{Data Understanding and Preparation}

The survey data has been acquired from the different locations (Bengaluru, Chennai, Delhi, Mumbai) and through various different channels (Email, online survey, hard copy form). The questionnaire consists of demographic (1-2), frequencies (3-5) of watching movie or TV and the rest are based on brand impact except the last point (19) which is a derived score. The answer has been obtained in a 5 points Likert scale. The question type and data dictionary are listed in the following table. 
Table: 1

\begin{tabular}{|c|c|c|c|c|}
\hline S.N & Features & $\begin{array}{l}\text { Missing } \\
\text { Count }\end{array}$ & Type & Top Values \\
\hline 1. & Gender & 0 & factor & Female, Male \\
\hline 2. & Age & 0 & factor & $\begin{array}{l}\text { 20-29, 30-39, Under } \\
\text { 20, Above } 50,40-49\end{array}$ \\
\hline 3. & How often do you watch films every month & 0 & $\begin{array}{l}\text { intege } \\
\mathrm{r}\end{array}$ & $\begin{array}{l}\text { Min: } 0, \text { Max: } 30, \\
\text { Mean: } 6.71\end{array}$ \\
\hline \multicolumn{5}{|l|}{4.} \\
\hline 5. & How often do you watch TV shows every month & 0 & $\begin{array}{l}\text { intege } \\
\mathrm{r}\end{array}$ & $\begin{array}{lll}\text { Min: } & 0, \quad \text { Max: } & 30, \\
\text { Mean: } 18.29\end{array}$ \\
\hline 6. & Do you watch reality shows on television & 0 & $\begin{array}{l}\text { logica } \\
\text { l }\end{array}$ & NA \\
\hline 7. & $\begin{array}{l}\text { Are you aware of Product Placements in films and } \\
\text { Television }\end{array}$ & 0 & $\begin{array}{l}\text { logica } \\
\text { l }\end{array}$ & NA \\
\hline 8. & $\begin{array}{l}\text { I have no problems with product placements } \\
\text { appearing in television and films }\end{array}$ & 0 & factor & $3,1,2,5,4$ \\
\hline 9. & $\begin{array}{l}\text { The presence of branded products in movies and TV } \\
\text { make it more realistic }\end{array}$ & 0 & factor & $2,3,1,5,4$ \\
\hline 10 & $\begin{array}{l}\text { I like to see product placements in my favorite film } \\
\text { or TV show }\end{array}$ & 0 & factor & $3,2,1,4,5$ \\
\hline 11 . & $\begin{array}{l}\text { Product Placements do not damage my opinion } \\
\text { against a brand or product }\end{array}$ & 0 & factor & $3,2,4,1,5$ \\
\hline 12 . & $\begin{array}{l}\text { I do not have a problem when a brand is very } \\
\text { noticeable in a movie or TV show }\end{array}$ & 0 & factor & $5,4,3,2,1$ \\
\hline 13. & $\begin{array}{l}\text { Product Placements are more acceptable when they } \\
\text { are hard to notice }\end{array}$ & 0 & factor & $3,2,1,4,5$ \\
\hline 14 & $\begin{array}{l}\text { I prefer when for example a character is shown } \\
\text { driving a BMW without the brand being mentioned } \\
\text { or focused upon }\end{array}$ & 0 & factor & $1,2,3,4,5$ \\
\hline 15. & $\begin{array}{l}\text { I prefer when product placements are a part of the } \\
\text { storyline }\end{array}$ & 0 & factor & $3,2,1,4,5$ \\
\hline 16. & $\begin{array}{l}\text { I get positively influenced by a product placement } \\
\text { when my favorite celebrity is associated with it }\end{array}$ & 0 & factor & $3,2,1,4,5$ \\
\hline 17. & $\begin{array}{l}\text { I get inclined to buy a product when I see it in a } \\
\text { movie or TV show }\end{array}$ & 0 & factor & $3,2,1,5,4$ \\
\hline 18. & $\begin{array}{l}\text { I frequently buy brands that are placed in TV shows } \\
\text { and films }\end{array}$ & 0 & factor & $3,4,2,5,1$ \\
\hline 19. & $\begin{array}{l}\text { I can easily recall a product placement while making } \\
\text { a purchase }\end{array}$ & 0 & factor & $2,3,1,4,5$ \\
\hline 20 & Brand Awareness Score & 0 & $\begin{array}{l}\text { nume } \\
\text { ric }\end{array}$ & $\begin{array}{l}\text { Min: } 1.5 \text {, Max: } 4.33 \text {, } \\
\text { Mean: } 2.78\end{array}$ \\
\hline
\end{tabular}

\section{Data Dictionary}

To understand the distribution of data, exploratory data analysis has been done for each question individually and in the combination with other questions. The graphs (only a few have been pasted here) have been given below.

The following graph is for Age and with an average value of "Brand Awareness Score". The first graph illustrates that maximum count (around 80) of responses are in age range 20-29 and for the rest of the age range the count is around 20. The distribution is right-skewed. The second graph illustrates the age with respect to "Brand Awareness Score". The highest mean score (3) is given by age range 40-49 and lowest mean score (2.5) is given by the age under 20 . The overall mean is more or equal to 2.5 signalling the positive trends. 
Figure: 1

Count of Age and with average value of "Brand Awareness Score"
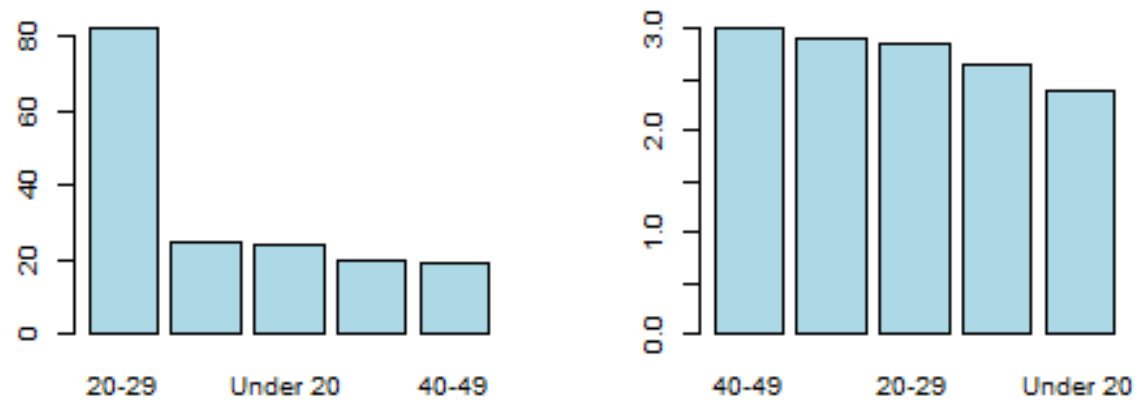

○ Similarly, all features have been analysed individually and with respect to response variable, "Brand Awareness Score".

- The following graph shows the Age and Gender's distribution with each other. A maximum number of responses are from Female. In both genders, the count of respondents is higher in the age range of 20-29.

Figure: 2

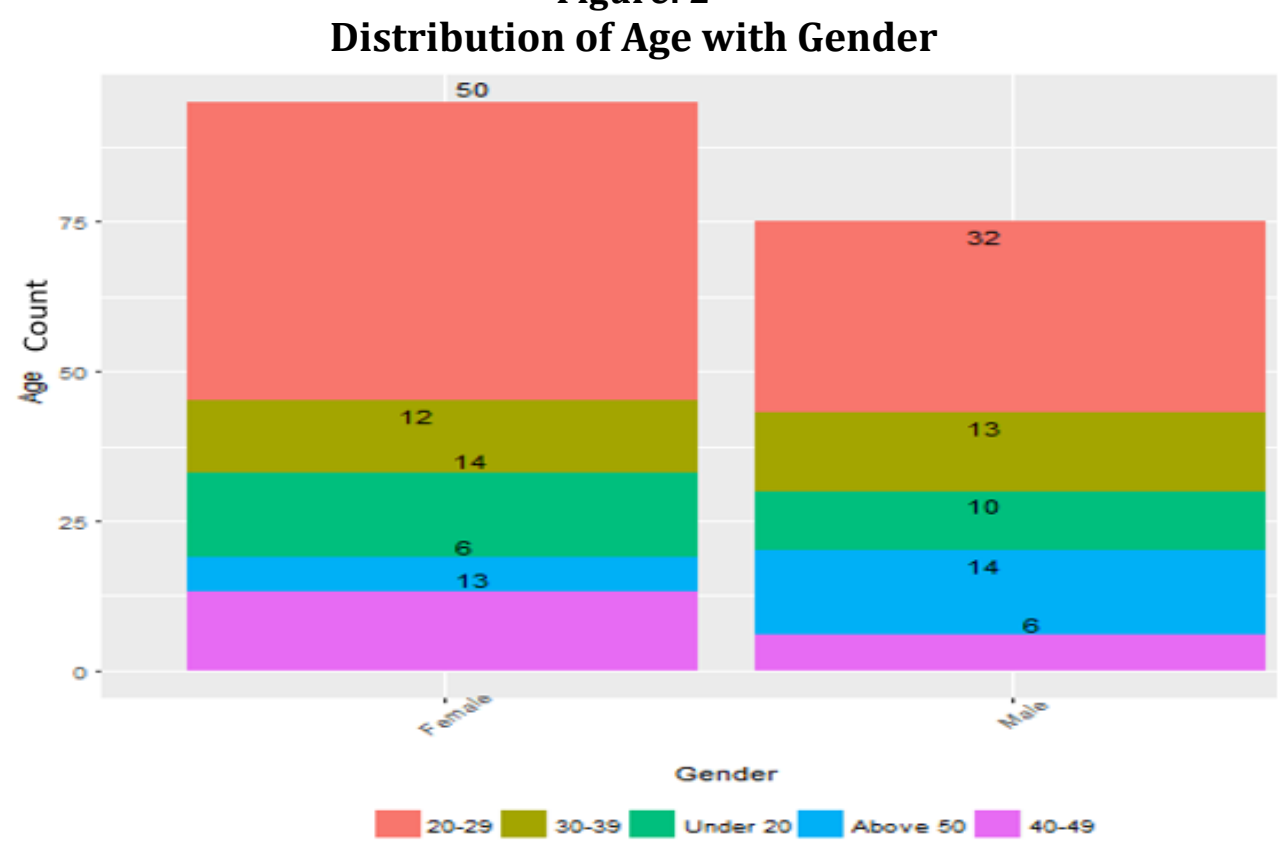

- In this way, all demographic features were analysed together.

- All questions' responses were analysed with other questions' responses. The following graph is one of the example. The first graph illustrates that the maximum number of respondents have chosen 5 "Highly Agree" for a question "I do not have a problem when a brand is very noticeable in a movie or TV show". The same respondents have chosen 3 "Neutral" for the question "Product Placements are more acceptable when they are hard to notice". The second graph illustrates that a maximum number of respondents are chosen 3 "Neutral" for a question "Product Placements are more acceptable when they are hard to notice". The same respondents have chosen 3 "Neutral" for the question "I prefer when for example a character is driving a BMW without the brand being mentioned or focused upon". 
Figure : 3

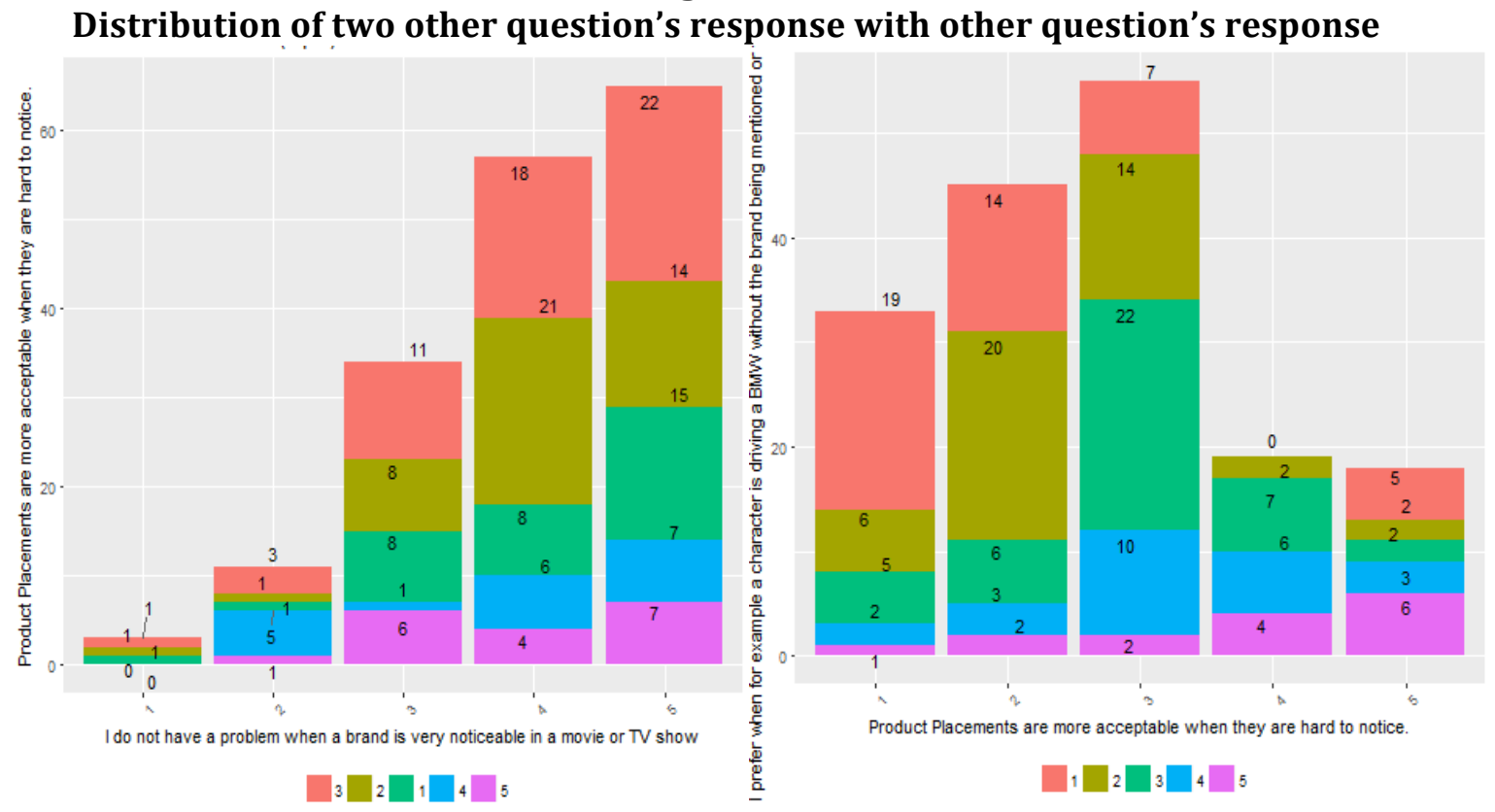

- Similarly, each question was analysed with respect to the other questions.

- The distribution of each independent and dependent variables were analysed. The distribution of Brand Awareness score is Normal and box plot shows few outliers.

Figure : 4

Distribution of Brand Awareness Score

Density of BrandAwareness Score

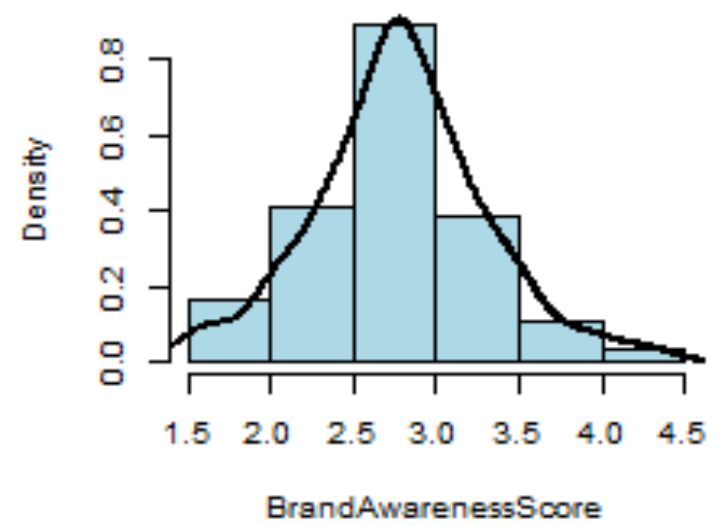

Spread of BrandAwareness Score

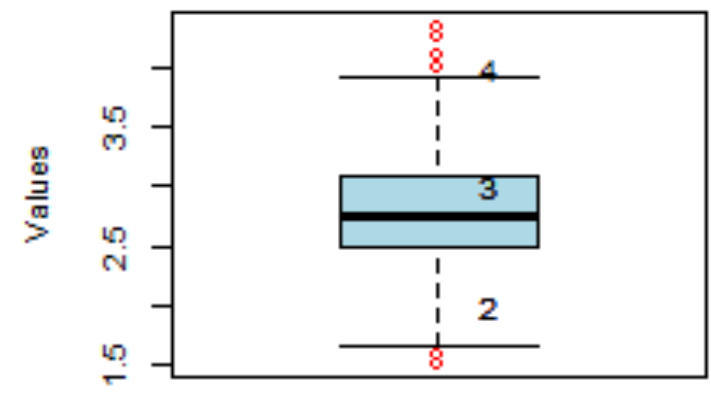

BrandAwarenessScore

Similarly, distribution of each variable was analyzed. One of the variable distribution is shown below. The first graph shows that distribution of respondents is right skewed for the question, "How often do you watch films every month" 


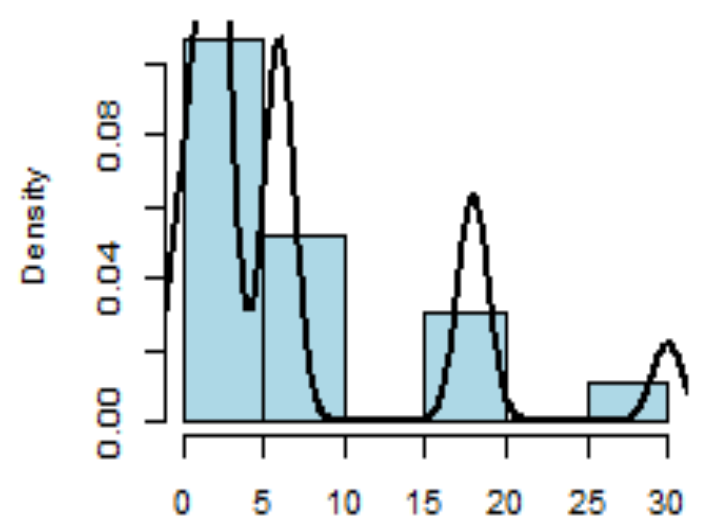

How often do you watch films every month

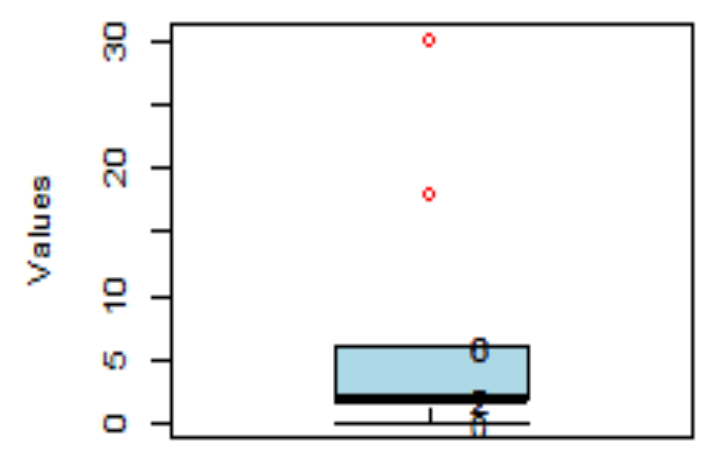

How often do you watch films every month

\section{Modeling}

- Data is now cleaned, transformed, analyzed and ready for modelling. First, we have build a model to assess the importance of each individual feature on the dependent variable "Brand Awareness Score" and then the combination of features on the dependent variable, "Brand Awareness Score" is measured using Association Analysis technique.

- To assess the importance of each individual feature, all independent variables (1-18) have been transformed and scaled as per the algorithm's requirement. The distribution of many independent variables are nonlinear and hence Random Forest from " $R$ " will be used to identify the important features on the dependent variable "Brand Awareness Score".

- To assess the importance of the combination of features, all independent variables, and the dependent variable have been transformed in categories so that the outcome can be read smoothly. The transformation has been done as follows.

\begin{tabular}{|l|l|l|l|}
\hline fbFeatures $\backslash$ Transformed Value & Low & Medium & High \\
\hline How often do you watch films every month & $<=2$ & $>2$ and $<8$ & $>=8$ \\
\hline $\begin{array}{l}\text { How often do you watch TV shows every } \\
\text { month }\end{array}$ & $<=6$ & $>6$ and $<22$ & $>=22$ \\
\hline \begin{tabular}{l} 
Brand Awareness Score \\
\hline
\end{tabular} & $<=2$ & $>2$ and $<3.5$ & $>=3.5$ \\
\hline
\end{tabular}

Table : 2

Transformed value for Association Analysis

The Association Analysis is built with support 30\% and confidence $80 \%$ and with minimum length 3 


\section{OUTCOMES}

The degree of importance on dependent variable "Brand Awareness Score" is illustrated in the following table.

\begin{tabular}{|c|c|c|}
\hline Feature Name & IncMSE & IncNodePurity \\
\hline $\begin{array}{l}\text { I get positively influenced by a product placement when my } \\
\text { favorite celebrity is associated to it }\end{array}$ & 17.02 & 8.62 \\
\hline $\begin{array}{l}\text { The presence of branded products in movies and TV make it more } \\
\text { realistic }\end{array}$ & 16.39 & 8.68 \\
\hline $\begin{array}{l}\text { I get inclined to buy the product when I see it in a movie or TV } \\
\text { show }\end{array}$ & 14.22 & 7.7 \\
\hline $\begin{array}{l}\text { I have no problems with product placements appearing in } \\
\text { television and films }\end{array}$ & 11.19 & 3.59 \\
\hline I can easily recall a product placement while making a purchase & 10.48 & 4.22 \\
\hline I frequently buy brands that are placed in TV shows and films & 7.15 & 2.37 \\
\hline $\begin{array}{l}\text { Product Placements are more acceptable when they are hard to } \\
\text { notice }\end{array}$ & 6.05 & 1.42 \\
\hline $\begin{array}{l}\text { I prefer when for example a character is shown driving a BMW } \\
\text { without the brand being mentioned or focused upon }\end{array}$ & 6.03 & 1.03 \\
\hline I prefer when product placements are a part of the storyline & 5.9 & 1.3 \\
\hline I like to see product placements in my favorite film or TV show & 5.89 & 1.16 \\
\hline $\begin{array}{l}\text { I do not have a problem when a brand is very noticeable in a } \\
\text { movie or TV show }\end{array}$ & 5.64 & 1.19 \\
\hline $\begin{array}{l}\text { Product Placements do not damage my opinion against a brand or } \\
\text { product }\end{array}$ & 5.22 & 1.17 \\
\hline How often do you watch films every month & 4.2 & 0.67 \\
\hline Are you aware of Product Placements in films and Television & 2.2 & 0.19 \\
\hline Age & 0.14 & 1.16 \\
\hline Do you watch reality shows on television & 0 & 0.19 \\
\hline Gender & -0.77 & 0.15 \\
\hline How often do you watch TV shows every month & -0.96 & 0.39 \\
\hline
\end{tabular}

Table : 3

The outcome of Random Forest Model showing importance of features

- As per the standard definition, the IncMSE is the most robust and informative measure. It is the increase in MSE of predictions (estimated with out-of-bag-CV) as a result of variable $\mathrm{j}$ being permuted (values randomly shuffled). The higher number, the more important 
- As per standard definition, the IncNodePurity relates to the loss function which by best splits are chosen. The loss function is MSE for regression, as the case here. More useful variables achieve higher increases in node purities, that is to find a split which has a high inter node 'variance' and a small intra node 'variance'.

Figure : 6

The outcome of Random Forest in Tree structure
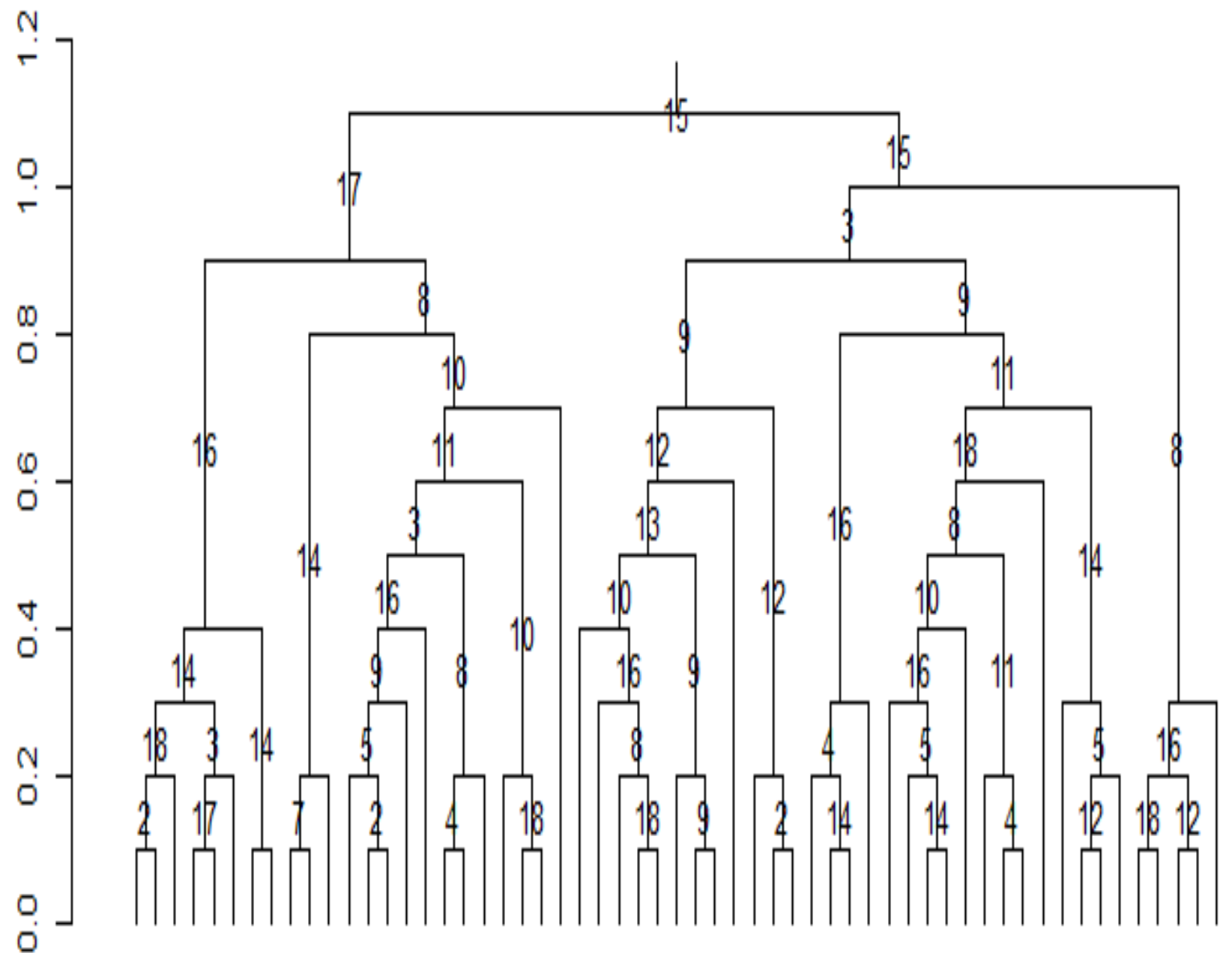

THE OUTCOME OF ASSOCIATION ANALYSIS

\begin{tabular}{|c|l|}
\hline Items & Support \\
\hline - Gender = Female & 0.34 \\
- Do you watch reality shows on television & \\
\hline - Do you watch reality shows on television & \\
- Are you aware of Product Placements in films and Television & 0.31 \\
\hline
\end{tabular}

Table : 4

Top 2 questions that going together

The above is depicted in the following graph. 
Figure : 7

Outcome of Association Analysis

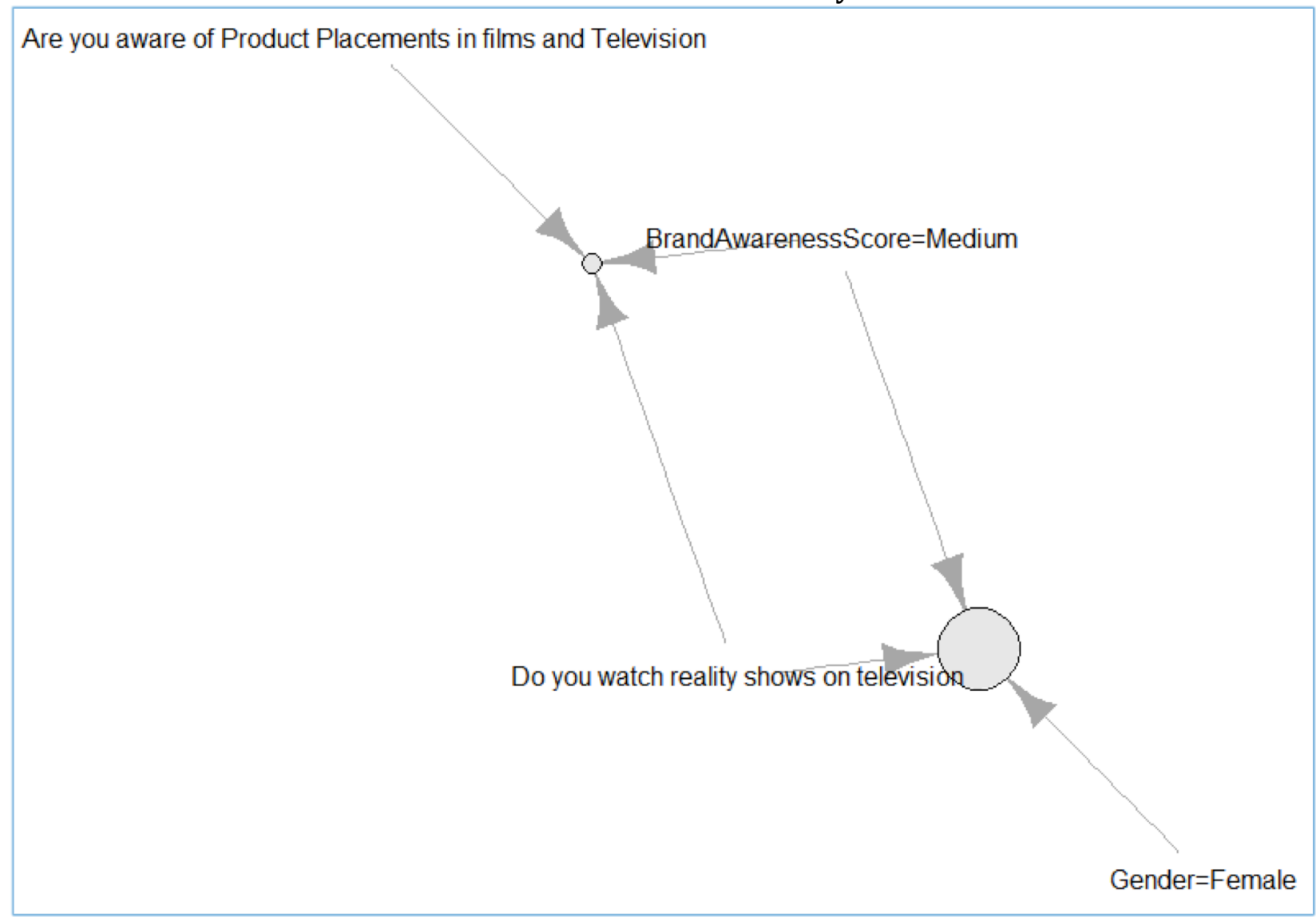

The questions "I get positively influenced by a product placement when my favorite celebrity is associated with it" and "The presence of branded products in movies and TV make it more realistic" have the highest impact on Brand awareness. It was further observed that questions "Do you watch reality shows on television and "Are you aware of Product Placements in films and Television" have a similar response from most of the people.

As per responses were analysed from the multiple advance Analytics, we can infer that Product Placements endorsed by celebrities have a substantial impact on the brand awareness of the viewers as well as their buying behaviour.

Hence, the alternative hypothesis have been accepted with the given evidence from the data and null hypothesis have been rejected.

\section{CONCLUSION}

The responses are maximum from female gender and in both gender age range 20-29 is dominating. The overall mean is equal to 2.78 that signals a positive trend. The Analysis happened from multidimensional as well as with other questions' responses. The distribution of Brand Awareness score is Normal with few outliers. It means that general responses have some consistent trends. The top three important responses impacting "Brand Awareness Score" are "I get positively influenced by a product placement when my favorite celebrity is associated with it", "The presence of branded products in movies and TV make it more realistic" and "I get inclined to buy a product when I see it in a movie or TV show". The least important features are "Age", "Do you watch reality shows on television", "Gender" and "How often do you watch TV shows every month". The question, "I get positively influenced by a product placement when my favorite celebrity is associated with it" and "The presence of 
branded products in movies and TV make it more realistic" have the highest impact on Brand awareness. It was further observed that questions, "Do you watch reality shows on television and "Are you aware of Product Placements in films and Television" have similar responses from most of the people.

As we see, the concept of product placements is not only growing at a fast pace but also growing popular among the masses. Marketers prefer using product placements in TV shows especially because people mostly tend to skip the commercial break during the shows. Today, people take notice of these brands and products while watching films or TV shows. Some may ignore it knowing that it's just a promotional strategy. However, they are also now slowly becoming positively influenced by such product placements. They prefer such placements when they are incorporated well into the storyline or when they see their favorite celebrities using it. They prefer it when these product placements are hard to notice or when they do not distract them from the storyline. Therefore, marketers need to bring out unique ways to grab a viewer's attention towards their product placements without causing disturbance to flow of the plot. Otherwise the brand/product may leave a negative impression in the minds of the viewers. Marketers also need to realize the potential of these product placements. As we can notice from the findings of this study most people do get inclined to buy products when they see it as product placements. However, most of theseare not resulting into purchases as of now. Also, viewers may not be sure if their purchases are being influenced by the product placements they see or by other advertising media. Therefore, these product placements have immense potential to influence the viewers, and marketers need to adopt strategies to make optimum use of product placements, which in turn will boost the sales of the company.

\section{Limitations of the study}

- Product Placements are minimal in Indian fictional show

- People may misunderstand TV commercials as product placements on television

- Product placements can easily be seen as disruptive marketing tools

- A sample of 170 respondents may be very less for the study

\section{Scope for Further Study}

The response count may be increased and outlier may be removed or substituted by max or min values. The same impact should be looked for in other media (Facebook, Twitter, Day to day formal or informal discussion).

For further studies, a detailed research could be done with regard to what kind of product placements are impactful on the viewers and what elements cause disturbance to the viewers. This may also include the variables that are strong enough to induce viewers to buy the product, which is shown as a product placement. Also, care needs to be taken as to avoid what the viewers find completely inappropriate to watch onscreen. This may include a study on their culture and traditions as well. A study could also be done on the various advertising media that induce consumer purchases and how much of these purchases are induced by product placements in films and television. This study may help marketers to develop new kinds of product placements, which are more influential in nature.

\section{References}

Aaker, David A. (1991), Managing Brand Equity, New York: The Free Press.

Ajzen, I., \&Fishbein, M. (1980).Understanding Attitudes and Predicting Social Behavior, New Jersey: Prentice-Hall. 
Alwitt, L., \& Prabhaker, P. (1994). Identifying Who Dislikes Television Advertising: Not by Demographics Alone. Journal of Advertising Research, 34(6), 17-29.

Anderson, John (1983). The Architecture of Cognition. Cambridge, MA: Harvard University Press.

Armstrong, I., Sands, M., Ward, S., \& Murray, M. (2009). Do advertisers have an appetite for product placement on television? . Journal of Advertising.

Athena Information Solutions Pvt. Ltd. . (2015). Consumers prefer entertainment marketing versus traditional forms.

Auty, S., \& Lewis, C. (2004). Exploring children's choice: The reminder effect of product placement. Psychology \& Marketing, 697-713.

Balasubramanian, Siva K., Karrah, James A., \& Patwardhan, H (2006). Audience Response to Product Placements. Journal of Advertising, 35(3), Fall, 115-141.

Belch, G., \& Belch, M. (2004). Advertising and Promotion - An Integrated Marketing Communications Perspective. 6th edition. New York, NY: McGraw-Hill/Erwin.

Bhatnagar, N., \& Wan, F. (2011). Is Self-Character Similarity Always Beneficial: The Moderating Role of Immersion in Product Placement Effects. Journal of Advertising, 40, 39-50.

Boeing, R., Urdan, A., \& Gentry, J. (2013). I saw it in the movies, but does that matter? Product placement in a cross cultural study between brazil and the USA . Revista Brasileira de Marketing,.12, 1-27.

Boerman, S., Reijmersdal, E., \& Neijens, P. (2015). Using Eye Tracking to Understand the Effects of Brand Placement Disclosure Types in Television Programs . Journal of Advertising.

Brennan, I., \& Babin, L. A. (2004). Brand Placement Recognition: The Influence of Presentation Mode and Brand Familiarity. Journal of Promotion Management, 10(1), 185-202.

Chiţu, I. B., \& Tecău, A. S. (2010). Product placement as a form of advertainment . Bulletin of the Transilvania University of Braşov ,3, 23-26.

Consumers, C. A. (2006). Russell, Cristel Antonia; Stern, Barbara B . Journal of Advertising, 7-21.

Cowley, E., \& Barron, C. (2008). When product placement goes wrong: The effects of Program Liking and Placement Prominence. Journal of Advertising, 89-98.

Eised, M., \& Moller, J. (2006). The influence of TV viewing on consumers body images and related consumption behavior. 101-116.

Gillespie, B. J., \& Muehling, D. (2012). The MoDeraTinG effecT of eGo DepleTion on Viewer BranD recoGniTion anD BranD aTTiTuDes following exposure To suBTle Versus

Gillespie, B., Joireman, J., \& Muehling, D. (2012). The Moderating Effect of Ego Depletion on Viewer Brand Recognition and Brand Attitudes following Exposure to Subtle Versus Blatant Product Placements in Television Programs. Journal of Advertising, 41(2). Summer, 55-65.

Guennemann, F. (2014). The Effectiveness of Product Placement By Media Types: Impact of Image and Intention to Purchase. Journal of Service Science- Volume 7, 29-42.

Gupta, P., Balasubramanian, S., \& Klassen, M. (2000). Viewers' Evaluation of Product Placements in Movies: Public Policy Issues and Managerial Implications. Journal of Current Issues and Research in Advertising, 22(2), 41-52.

Gupta, P., \&Gould, S.(1997). Consumers' Perceptions of the Ethics and Acceptability of Product Placement in Movies: Product Categories and Individual Differences. Journal of Current Issues and Research in Advertising, 19(1), 37-50.

Gupta, Pola and Lord, Kenneth (1998), Product Placement in Movies: The Effect of Prominence and Mode on Audience Recall. Journal of Current Issues and Research in Advertising, 20(1), 47-59.

Habil. (2015). Indicators and Methodologies for the Assessment of Product Placement. Journal of Media Research, 27-40.

Hackley, C., Tiwsakul, R., \&Amy ,H .(2012). Unpaid Product Placement: The Elephant in the Room in UK TV's New Paid-for Product Placement Market. International Journal of Advertising, 31(4), 703-718. 
Hang, H., (2014). Brand-Placement Effectiveness and Competitive Interference in Entertainment Media: Brand Recall and Choice in Kids' Video-Game Advertisements. Journal of Advertising Research, June, 192-199.

Homer, P. M. (2009). Product Placements: The Impact of Placement Type and Repetition on Attitude. Journal of Advertising, 21-31.

Hudson, S., Hudson, D., \& Peloza, J. (2008). Journal of Business Ethics , 289-304.

Jan, K., \& Martina, K. (2013). Product Placement: A Smart Marketing Tool Shifting a Company to the Next Competitive Level . Journal of Competitiveness Vol.5, 98-114.

Johnstone, E., \& Dodd, C. (2000). Placements as Mediators of Brand Salience within a UK Cinema Audience. Journal of Marketing Communications, 6, 141-158.

K, R., \& Saxena, R. (2015). Celebrity Star Association for Tacit Endorsement of Brands in Entertainment Context An Experimental Study. Asia Pacific Journal of Management \& Entrepreneurship Research (APJMER), 67-88.

Karniouchina, E. V., Uslay, C., \& Erenburg, G. (2011). Do Marketing Media Have Life Cycles? The Case of Product Placement in Movies. Journal of Marketing, 75. May, 28-48.

Karrh, J. (1998). Brand Placement: A Review. Journal of Current Issues and Research in Advertising, 20(2). 31-49.

Karışık, V. (2014). 20 Years of Research on Product Placement in Movie. Journal of Economic and Social Studies, 253-283.

Keller, K. (2008). Strategic Brand Management - Building, Measuring, and Managing Brand Equity, 3rd edition. Upper Saddle River, NJ: Prentice Hall.

Kinard, B., \& Hartman, K. (2013). Are You Entertained? The Impact of Brand Integration and Brand Experience in Television-Related Advergames . Journal of Advertising, 196-203.

Kong, F., \& Hung, K. (2012). Product Placement in Television Drama: Do Information Overload and Character Attribute Matter? . International Journal of Trade, Economics and Finance, 3 (2), 96-102.

Lawrence, R. (1989). Television: The Battle for Attention. Marketing and Media Decisions, 24(2), 80-84.

Law, S., \& Braun, K. (2000). I'll Have What She's Having: Gauging the Impact. Psychology \& Marketing, 17(12), 1059-1075.

Lees, M., Scott, J., \& Wong, R. (2008). Perceptions of product placement practice across Australian and US practitioners . Marketing Intelligence \& Planning,26(5), 521-538.

Lehu, J.-M., \& Bressoud, É. (2009). Recall of Brand Placement in Movies: Interactions between Prominence and Plot Connection in Real Conditions of Exposure. Recherche et Applications en Marketing, 24, 7-26.

Markin, Rom (1979). Marketing. New York, NY: John Wiley \& Sons. In

McClellan, S. (2003). Reality Shows Line Up for Product Placement. Journal of Advertising, 28.

Mircea, O., \& Elena, D. (2015). Commercial breaks vs. product placement: what works for young consumers? . Bulletin of the Transilvania University of Braşov , 8, 71-78.

Nelson, M. R.., \&Deshpande, S. (2013). The Prevalence of and Consumer Response to Foreign and Domestic Brand Placement in Bollywood Movies. Journal of Advertising, 42(1). 1-15.

Noguti, V., and Russell, C. A. (2014). Normative Influences on Product Placement Effects: Alcohol Brands in Television Series and the Influence of Presumed Influence. Journal of Advertising, 43(1), 46-62.

Nunlee, M., Smith, D., \& Katz, M. (2012). Negative Product Placement: An Evolving Theory of Product Disparagement and Unfair Competition . Journal of Marketing Development and Competitiveness vol. 6(2), 11-21.

Patel, H., \& Chauhan, A. (April 2013). An Empirical Study of Effectiveness of Product Placement in Hindi Movies Compare to Television Shows. International Journal of Marketing and Business Communication ,2, 24-31 .

Peluso, A., Tedeschi, P., \& Nicole, C. (2010). Acceptance of Product Placement in Italy: Effects of Personality and Product/Consumer Interactions . International Journal of Marketing Studies, 2, 34-46. 
Petroll, M., \& Prado, P. (2014). A Theoretical Essay on TV Show Placement and Its Effects on Consumers . RAC, Rio de Janeiro, 18, 176-195.

Robinson, N., Hutchison, J., Clay, L., \& Connolly, D. (2011). Will product placement greatly increase the effectiveness of marketing on TV? . 20.

Rovella, M., Geringer, S., \& Sanchez, R. (2015). Viewer Perception of Product Placement in Comedic Movies. American Journal of Management ,15(1), 36-49.

Russell, A., \& Stern, B. B. (2006). Consumers, characters, and products: A Balance Model of Sitcom Product Placement Effects . Journal of Advertising, 7-21.

Saevarsson, h., \& Sigurdsson, v. (2009). Brand placement and consumer choice: an in-store experiment . Journal of applied behavior analysi, 741-745.

Sharma, K., \& Nayak, N. (March 2015). Product Placement: Does it lead brand recall among Indian Consumers? Intenational Journal of Business and Management,.10, 244-250.

Singh, S., Mishra, S., Bendapudi, N., \& Linville, D. (1994). Enhancing Memory of Television Commercials through Message Spacing,.Journal of Marketing Research, 31, August, 384-393.

Soba, M., \& Aydin, M. (2013). Product Placement Efficiency in Marketing Communication Strategy. International Journal of Business and Management Vol. 8, 111-116.

Steortz, E. (1987). The Cost Efficiency and Communication Effects Associated with Brand Name Exposure within Motion Pictures, unpublished master's thesis, West Virginia University.

Taejun, L., Yongjun, S., \& Federio, G. (2011). Cross Cultural Challenges in Product Placement. Marketing Intelligence and Planning, 366-384.

Toomey, D., \& Francis, A. (2013). Branded product placement and pre-teenaged consumers: influence on brand preference and choice. YOUNG CONSUMERS 14, 180-192.

Valenzuela, L., Martínez, C., \& Yáñez, F. (2015). Influence of Placement on Explicit and Implicit Memory of College Students. Media Education Research Journal, 169-176.

Waldt, D., Toit, L., \& Redelinghuys, R. (2007). Does branded product placement in film enhance realism and product recognition by consumers? . African Journal of Business Management , 19-25.

Wiles, M., \& Danielova, A. (2009). The Worth of Product Placement in Successful Films: An Event Study Analysis. Journal of Marketing, 44-63.

Wyer Jr., Robert., \&Srull, T.(1989). Person Memory and Judgment. Psychological Review, 96(1), 58-83.

Yoon, S., Choi, Y., \& Song, S. (2011). When Intrusive Can Be Likable:Product Placement Effects on Multitasking Consumers. Journal of Adverising ,40, 63-75

Zazza, Frank (2002). Product Placement Valuation \& Product Placement. 